\title{
Solutions for Energy Conservation and Pollution Reduction: Earth-Air Heat Exchangers
}

\author{
Cătălin Teodosiu, Lidia Niculiță, and Raluca Teodosiu
}

\begin{abstract}
The aim of this work is to evaluate the capacity of earth-air heat exchanger (EAHX) systems to contribute to energy and pollution savings for heating and cooling of buildings. This is fulfilled by means of numerical simulations (dynamic regime) based on coupled model: "weather file/soil model/EAHX/ventilation system/building. Detailed results concerning EAHX efficiency, energy conservation and pollution reduction (in comparison with classical solutions for winter heating and summer cooling), are shown for three different Romanian regions for a single-family separate house.
\end{abstract}

Index Terms-Earth-air heat exchanger, energy saving, greenhouse gas emission reduction, modeling, simulation, ventilation.

\section{INTRODUCTION}

The energetic sector, including private households and tertiary field, generates $80 \%$ of European Union (EU) total greenhouse gas emissions (GES), being practically the main cause of climatic changes and atmospheric pollution. Consequently, EU has made efforts to find out solutions for decreasing the amount of GES (within EU and worldwide) associated to energy use in order to slow down climatic changes and therefore to limit the global warming [1]. In fact, the major European Union (EU) objective is to increase the energy efficiency by $20 \%$ and to reduce the GES by $20 \%$ until the year 2020 [2]. In line with this, according to The Energy End-Use Efficiency and Energy Services Directive (ESD 2006/32/EC), Member States (MS) must achieve a minimum annual energy savings target of $9 \%$ by the ninth year in the period from 2008 to 2016 . On the other hand, it is well known that buildings are responsible for more than $40 \%$ of total final energy consumption and $36 \%$ of $\mathrm{EU} \mathrm{CO}_{2}$ emissions [3]. Furthermore, EU documents estimate even more energy consumption due to ventilation and cooling of houses in South Europe. Therefore measures to improve energy efficiency in this sector have a strong leverage effect.

As a result, for achieving the EU energy saving targets, the very low energy houses and passive houses technology will be an essential tool on this road [4], [5]. This field of action can significantly help to challenge recent pessimistic reports suggesting that current EU measures could achieve energy savings of only about $13 \%$ by 2020 . In fact, following the

Manuscript received May 26, 2014; revised July 28, 2014. This work was supported by the Romanian National Authority for Scientific Research, CNDI- UEFISCDI under Grant PN-II-ID-JRP-RO-FR-2012-0071.

The authors are with the Thermo-Hydraulic and Protection of the Atmosphere Systems Department, Faculty of Building Services and Equipment, Technical University of Civil Engineering, Bucharest 020396, Romania (e-mail: cteodosiu@yahoo.com, niculita@gmail.com, ralucahohota@yahoo.com).
European Commission's proposal in November 2008 for an update of the 2002 Energy Performance of Buildings Directive (EPBD), the Recast was adopted by the European Parliament and the Council of the EU on 19 May 2010 (European Directive 2010/31/EU). One of the highlights of the recast is a strengthening of the energy performance requirements of new as well as existing buildings across the EU. The timescales are mentioned in Article 9 of the Directive, which states that MS shall ensure that "by 31 December 2020, all new buildings are nearly zero-energy buildings and after 31 December 2018, new buildings occupied and owned by public authorities are nearly zero-energy buildings." The EPBD Recast definition of very low energy building was agreed to: "nearly zero energy building means a building that has a very high energy performance" and "the nearly zero or very low amount of energy required should to a very significant level be covered by energy from renewable source, including renewable energy produced on-site or nearby". In addition, it is worthwhile to mention that the ventilation system is indispensable in this case as these buildings are extremely well thermal insulated and air tightened.

In this perspective, the use of geothermal heat exchangers for heating and/or cooling of buildings has experienced lately a growing interest. Among these equipments, the earth-air heat exchangers (EAHXs) represent the simplest technical solution. Despite its simplicity (in fact, this is an advantage from all points of view: execution, maintenance, payback, etc.), earth-air heat exchangers lead to important energy savings concerning fresh air supply within ventilation systems of buildings during all the year [6]. Consequently, the objective of this study is to fulfill methodical numerical investigation in order to quantify energy and GES emissions savings, achieved by using earth-air heat exchangers added to ventilation systems for Romanian conditions (climate and typical dwelling built up according to national standards).

\section{GROUND TO AIR HEAT EXCHANGER SYSTEM}

The system functioning is based on outside air circulated through pipes buried in the ground (Fig. 1). The heat exchange takes place between the ground and the air inside the pipes: earth's temperature varies from 2-3 meters depth within $5 \ldots 15^{\circ} \mathrm{C}$ all year round, while outside air temperature can range from $-20 \ldots 40^{\circ} \mathrm{C}$, if we refer to situations encountered in Romania. In consequence, at the end of the buried pipes, heat transfer leads to air heating or cooling, depending on the season. Depending on working conditions (length, diameter, thermal conductivity and depth of the tube, air flow, soil characteristics, etc.), the air temperature 
difference in/out earth-air heat exchanger can reach $10 \ldots 15^{\circ} \mathrm{C}$.

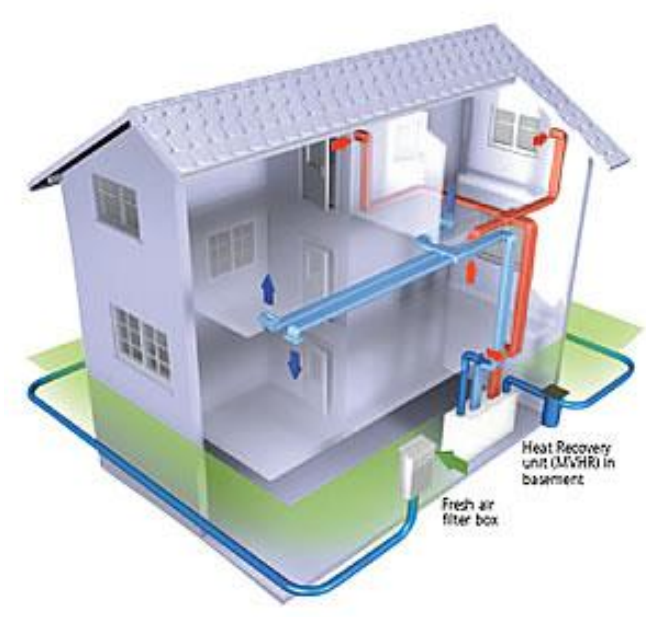

Fig. 1. Earth-air heat exchanger system (REHAU).

In fact, the thermal performance of earth-air heat exchangers can be theoretically appreciated by means of achieved heat transfer efficiency (or "temperature ratio" [7]):

$$
\eta=\left(T_{i}-T_{o}\right) /\left(T_{i}-T_{S}\right)
$$

where:

$T_{i}$ : inlet EAHX air temperature (outside air temperature)

$T_{o}$ : outlet EAHX air temperature

$T_{S}$ : soil temperature

It is worthwhile to mention that higher efficiency takes place in the summer. Moreover, the air is also dehumidified in the summer due to condensation that occurs on the inner surface of pipes. This helps also to improve thermal comfort and energy savings for air treatment in summer.

\section{NUMERICAL MODELING}

In order to thorough investigate the behavior of the ground to air heat exchanger, numerical modeling is the most relevant research tool. Therefore, there are numerous studies dealing recently with this subject [8]-[13]. Most of these studies have focused on the heat transfer soil - pipe heat exchanger, taken carefully into account thermal inertia of the ground. In addition, there are also analysis focused on the effect of air velocity and its turbulence on the performance of the ground to air heat exchanger system. These works are mainly based on computational fluid dynamics approach [14]-[16].

On the other hand, there is several simulation tools that can be used for modeling and simulation of the phenomena related to the earth-air heat exchanger thermal conduct: Design Builder + Energy Plus, Pleiades + Comfie, Trnsys, eQuest (DOE-2), Voltra, WTK2, WKM, etc. Among these, by far the best known and used specialized software is TRaNsient SYstem Simulation Software Program - TRNSYS environment [17].

In fact, Trnsys is flexible, modular software designed to simulate the energy performance of dynamical systems. It is commercially available since 1975 . Nowadays, Trnsys has become a reference worldwide in the field of simulation of buildings and systems behavior in dynamic regime. Some 50 families of components ("types"), available in standard library, allow simulating, in transient conditions: buildings (mono or multi zonal), the simplest as the most complex heating and cooling systems, innovative building services and equipment systems, etc. Other components can couple the simulation with the weather, building occupancy (scenario concerning internal loads), use of different forms of energy, and generate the desired outcomes.

As a result, we developed comprehensive Trnsys simulation models in dynamic regime for coupling building-ventilation (with earth-air heat exchanger system). The main components of these models and their inter-connections are shown in Fig. 2.

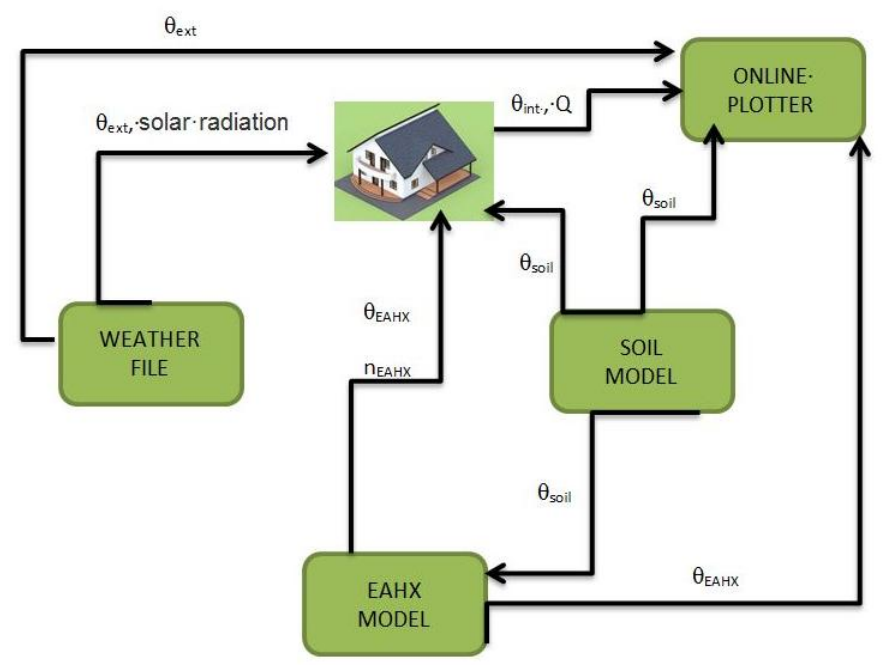

Fig. 2. Key of the numerical model.

Furthermore, we present below the characteristics of the main model components (weather data, building, soil, buried pipe model), as well as the main assumptions taken into consideration.

- Weather data, based on "weather file" has the following major objective: reading weather data at regular intervals from a data file, conversion to a desired system of units and processing solar radiation data to obtain tilted surface radiation and the angle of incidence for an arbitrary number of surfaces. In our study we used the file with weather data for 3 Romanian cities (these data contain the outdoor temperature, humidity and solar radiation - direct, diffuse and global).

- Building, component for the house thermal behavior modeling contents non-geometrical balance model with one air node per zone, representing the thermal capacity of the zone air volume; the balance equation takes mainly into account convective heat flux to the air node, coupling between zones by means of air mass flow, radioactive heat flux to the walls and windows [17]. The walls are modeled using transfer function technique (response factors).

- Soil, is the model component which describes the vertical distribution of ground temperature considering the annual mean temperature of the surface, the amplitude of the soil annual surface temperature, thermal diffusivity of the soil. These values can be found in the literature depending on the nature of the soil (dry sand, wet sand, dry loam, wet loam, etc.) [18], [19]. Moreover, the following assumptions are 
taken into account: the soil is homogenous and the soil type does not change around and along the tube of the earth-air heat exchanger.

- Buried pipe model for air to soil heat transfer (the buried pipe is surrounded by a 3-dimensional finite difference conduction network). The proposed model is developed particularly for building energy transient simulations, thus the following hypothesis have been made: only conduction heat transfer is taken into account; the influence of moisture transfer or ground water flows are neglected; ground thermal properties are considered homogenous in the vicinity of the pipe. Axial heat transfer in the soil along the pipe is neglected and the conductive heat transfer is also neglected inside the pipe. Furthermore, it is also assumed that the pipe material used is isotropic and homogeneous.

Finally, all thermophysical properties are considered constant and they are evaluated at an average temperature.

\section{CASE Study}

We introduce in this section the main characteristics of our case study.

\section{A. Building}

The house taken into account is characteristic for the new dwellings built up in Romania nowadays (single-family separate house). The building has ground floor and two levels (total floor area and total volume are $120 \mathrm{~m}^{2}$ and $324 \mathrm{~m}^{3}$, respectively). Other geometrical characteristics are shown in Table I.

\begin{tabular}{cccc}
\multicolumn{4}{c}{ TABLE I: ENVELOPE ELEMENTS SURFACES $\left(\mathrm{M}^{2}\right)$} \\
\hline \hline $\begin{array}{c}\text { Windows } \\
(\mathrm{N}, \mathrm{S}, \mathrm{E}, \mathrm{W})\end{array}$ & $\begin{array}{c}\text { Walls } \\
(\mathrm{N}, \mathrm{S}, \mathrm{E}, \mathrm{W})\end{array}$ & $\begin{array}{c}\text { Roof } \\
\text { (horizontal) }\end{array}$ & $\begin{array}{c}\text { Floor on } \\
\text { ground }\end{array}$ \\
\hline 35.84 & 119.04 & 60.00 & 60.00 \\
\hline \hline
\end{tabular}

Envelope thermal insulation of the house is according to national technical regulations [20]. Thermal resistance values for each envelope element are given in Table II (including also these values corrected by thermal bridges - specified between parentheses).

TABLE II: ENVELOPE THERMAL RESISTANCES $\left(\mathrm{M}^{2} \cdot \mathrm{K} / \mathrm{W}\right)$

\begin{tabular}{cccc}
\hline \hline Windows & Walls & Roof & Floor on ground \\
\hline \multirow{2}{*}{0.787} & 3.369 & 5.263 & 6.622 \\
& $(2.527)$ & $(5.105)$ & $(5.430)$ \\
\hline \hline
\end{tabular}

Internal loads taken into consideration within the simulations are according to common occupation of the dwelling ( 3 persons, $420 \mathrm{~W}$ from equipment and lighting, 5 $\left.\mathrm{W} / \mathrm{m}^{2}\right)$.

Temperature set points are as follows: winter $20^{\circ} \mathrm{C}$, summer $26^{\circ} \mathrm{C}$.

The house described above has been considered located in three Romanian cities, corresponding to different climatic zones of the country (Fig. 3 and Fig. 4): Constanta, on the Black Sea coast - moderate continental climate with considerable maritime and some subtropical influences (minimum/maximum outside air temperature: $-11,2^{\circ} \mathrm{C} / 31,1^{\circ} \mathrm{C}$ according to the Meteonorm weather database); Bucharest, capital - temperate humid continental climate (minimum/maximum outside air temperature: $-15,4^{\circ} \mathrm{C} / 35,4^{\circ} \mathrm{C}$ according to the Meteonorm weather database); Iasi, in the North-East of Romania - pronounced continental climate, influenced by air masses of Eastern origin, with very cold winters and hot summers (minimum/maximum outside air temperature: $-16,5^{\circ} \mathrm{C} / 33,0^{\circ} \mathrm{C}$ according to the Meteonorm weather database).

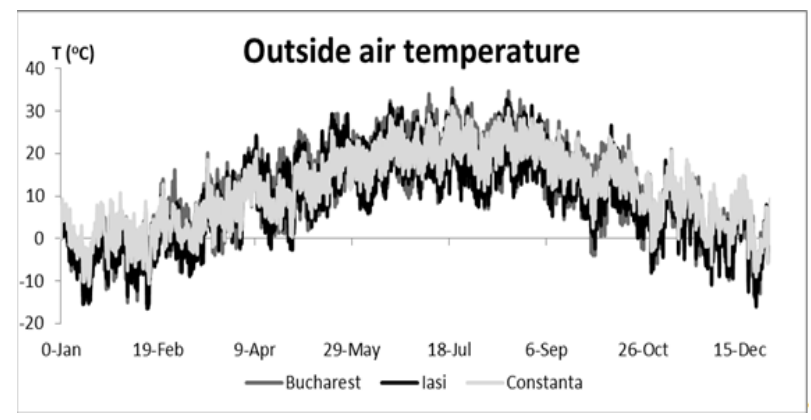

Fig. 3. External air temperature (Meteonorm weather database).

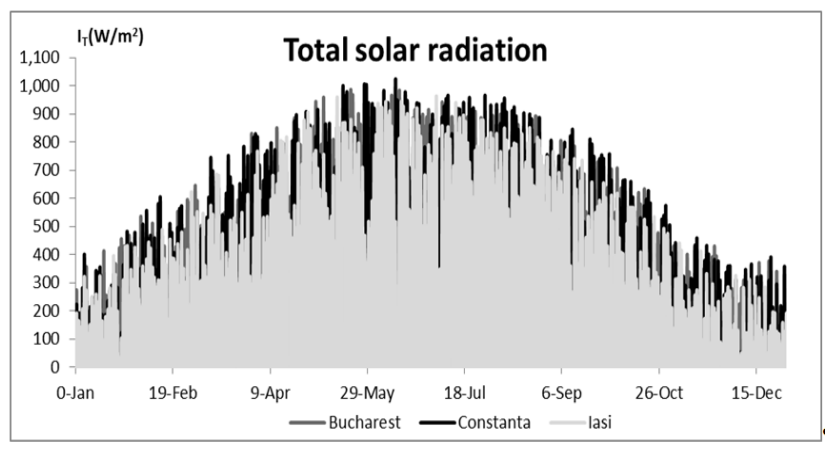

Fig. 4. Total solar radiation (Meteonorm weather database).

\section{B. Earth-Air Heat Exchanger System}

The fresh air flow rate of the house ventilation system is $162 \mathrm{~m}^{3} / \mathrm{h}$ (meaning $0.5 \mathrm{~h}^{-1}$ ).

Table III presents the main thermal properties of the earth-air heat exchanger pipe.

TABLE III: EAHX PIPE CHARACTERISTICS

\begin{tabular}{ccc}
\hline \hline $\begin{array}{c}\text { Density } \\
\left(\mathrm{kg} / \mathrm{m}^{3}\right)\end{array}$ & $\begin{array}{c}\text { Specific heat } \\
(\mathrm{J} / \mathrm{kg} \cdot \mathrm{K})\end{array}$ & $\begin{array}{c}\text { Thermal conductivity } \\
(\mathrm{W} / \mathrm{m} \cdot \mathrm{K})\end{array}$ \\
\hline 900 & 2900 & 0.12 \\
\hline \hline
\end{tabular}

Pipe diameters taken into account during the simulations are: $110,160,200$ and $400 \mathrm{~mm}$. Tubes mounting depth is $2 \mathrm{~m}$ and the total length of the buried part of the system (the "active" heat transfer part) is $40 \mathrm{~m}$ (single pipe). These parameters have been chosen based on "rules of thumb" regarding the standard design of earth-air heat exchanger system for single-family houses up to $150 \mathrm{~m}^{2}$ floor area. In fact, previous studies [21] showed that, for shorter circuits $(25 \ldots 40 \mathrm{~m})$ the air temperature at the exit of the earth-air heat exchanger system does not approach the soil temperature, while bigger lengths do not lead to significant improvements of heat transfer.

\section{RESUlts}

The thermal behavior of the earth-air heat exchanger can 
be predicted by using its efficiency as shown above, based on equation (1). The annual mean earth-air heat exchanger efficiency for different situations is shown in Table IV, based on hourly time step simulations values.

It is worthwhile to notice that the outside air temperature annual variation (depending on the zone climate) has not any influence, in this case, on the earth-air heat exchanger annual effectiveness. This happens because the air temperature after passing the earth-air heat exchanger is approaching the ground temperature - basically the same, regardless the climate.

TABLE IV: EAHX EFFICIENCY (\%)

\begin{tabular}{cc}
\multicolumn{2}{c}{ TABLE IV: EAHX EFFICIENCY $(\%)$} \\
\hline \hline Solution / City & Constanța, Bucharest, Iaşi \\
\hline EAHX, D $=110 \mathrm{~mm}$ & 79.9 \\
\hline EAHX, D $=160 \mathrm{~mm}$ & 88.9 \\
\hline EAHX, D $=200 \mathrm{~mm}$ & 92.6 \\
\hline EAHX, D $=400 \mathrm{~mm}$ & 97.5 \\
\hline \hline
\end{tabular}

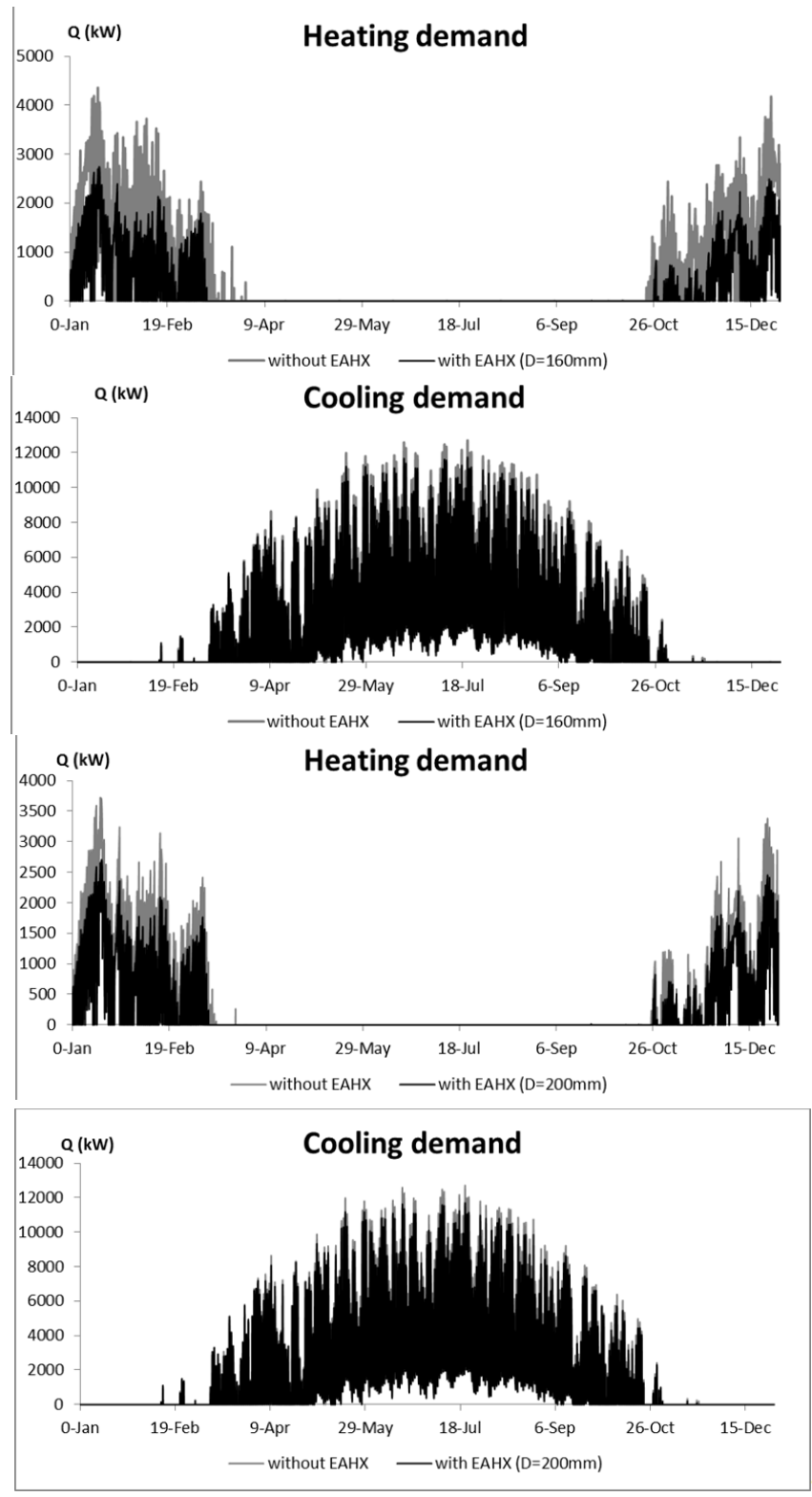

Fig. 5. Constanța (heating/cooling demand without/with EAHX).

Concerning the integration of the earth-air heat exchanger within the ventilation system, we show (Fig. 5- Fig. 7) the diminution of the winter heating power and summer cooling power for the cities taken into account. The comparisons are given for two diameters, $160 \mathrm{~mm}$ and $200 \mathrm{~mm}$, usually recommended for single-family houses with floor area between $100-150 \mathrm{~m}^{2}$.

Based on the previous results, we summarize in Table $\mathrm{V}$ the energy consumption values in various situations (without/with EAHX).
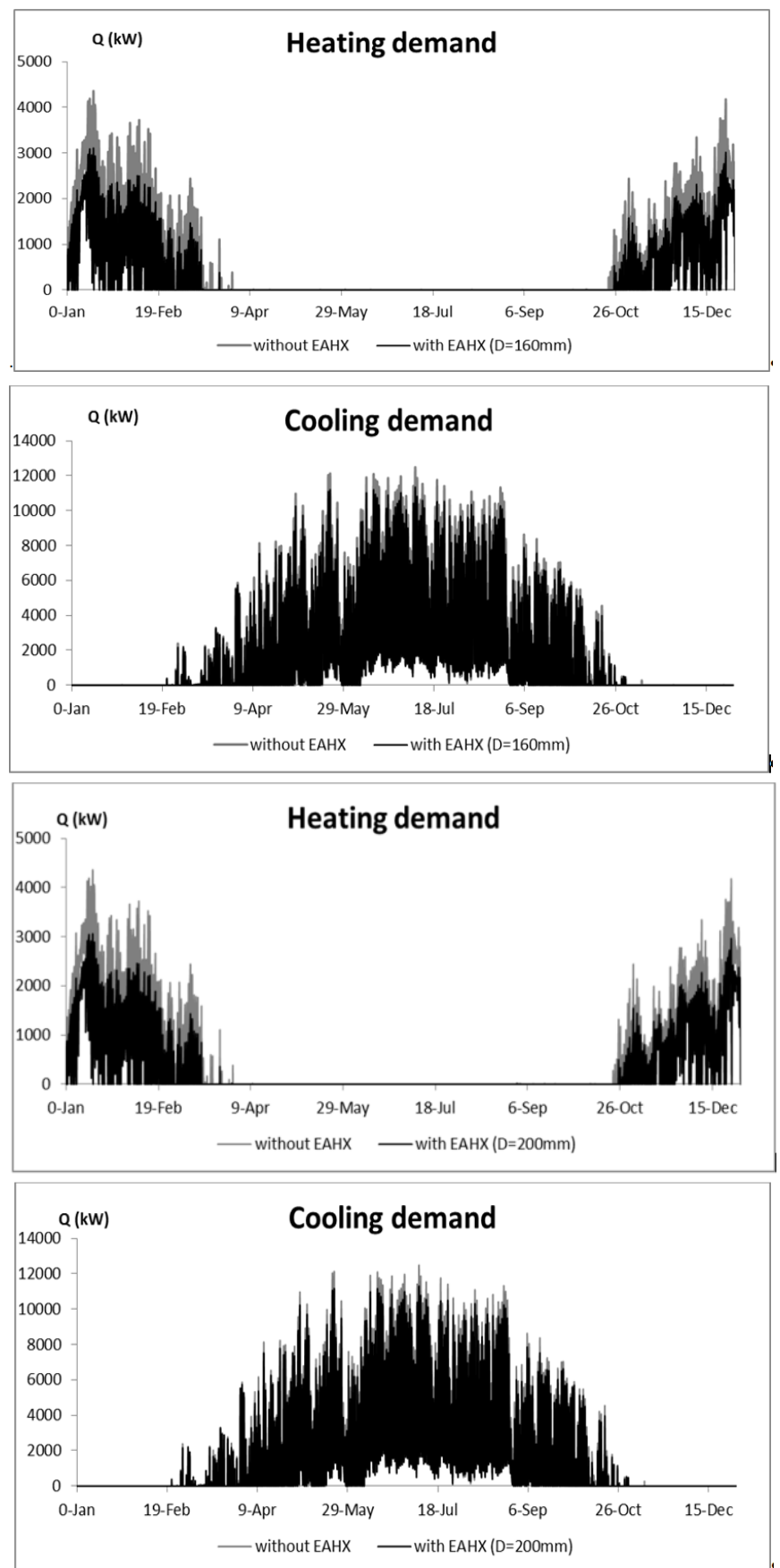

Fig. 6. Bucharest (heating/cooling demand without/with EAHX).

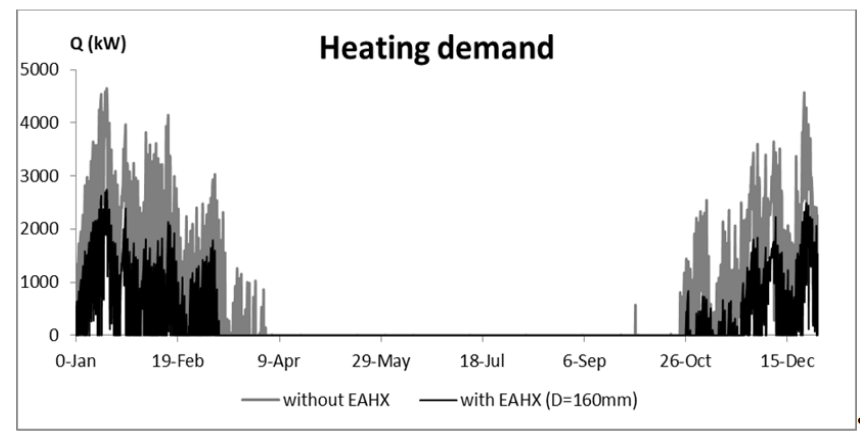



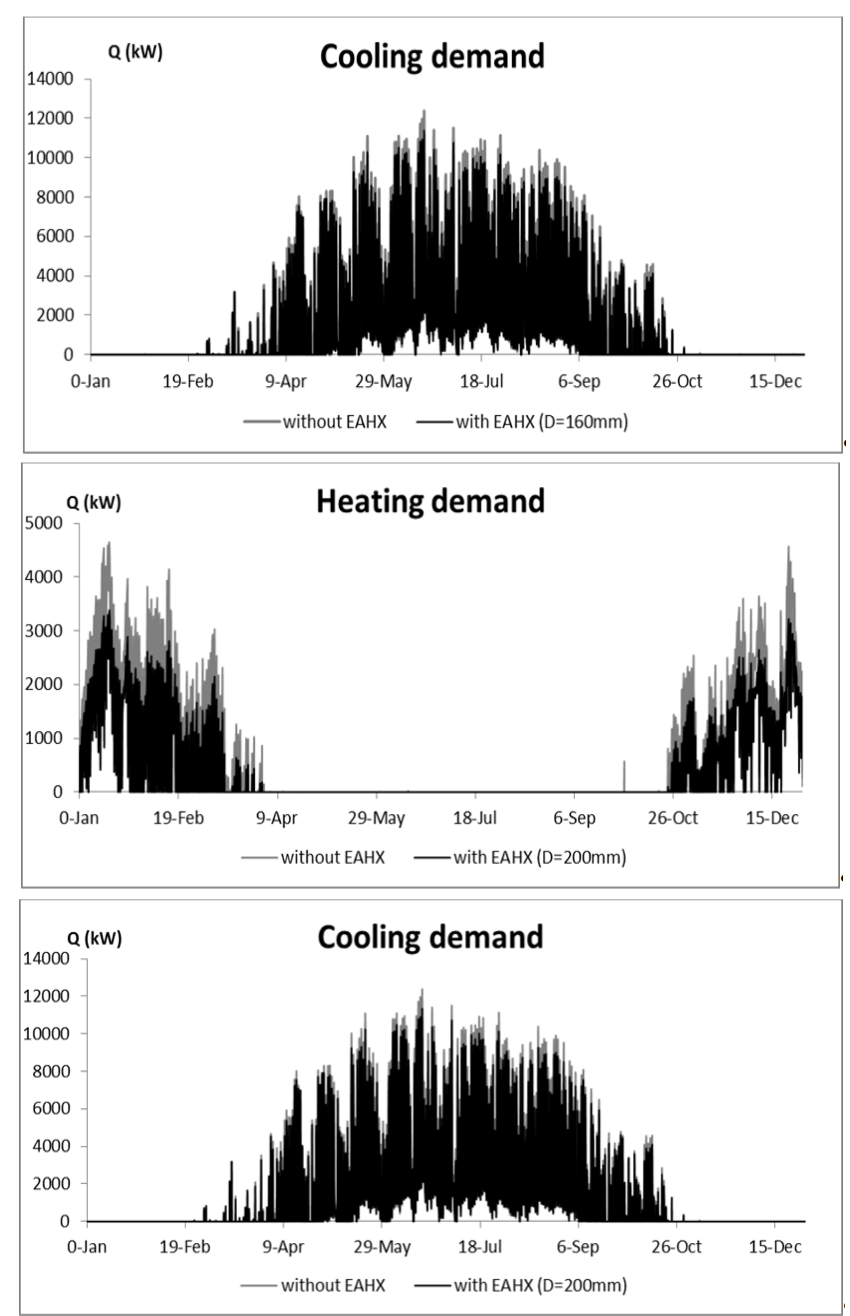

Fig. 7. Iaşi (heating/cooling demand without/with EAHX).

TABLE V: ENERGY CONSUMPTION (KWH/M², YEAR)

\begin{tabular}{ccc}
\hline \hline \multirow{2}{*}{ Solution / City } & \multicolumn{2}{c}{ Constanța } \\
\cline { 2 - 3 } & heating & cooling \\
\hline without EAHX & 30.03 & 143.91 \\
\hline EAHX, D = 110 mm & 21.79 & 130.27 \\
\hline EAHX, D = 160 mm & 20.88 & 128.75 \\
\hline EAHX, D = 200 mm & 20.52 & 128.1 \\
\hline EAHX, D = 400 mm & 20.02 & 127.31 \\
\hline \hline Solution / City & \multicolumn{2}{c}{ Bucharest } \\
\hline without EAHX & 40.98 & cooling \\
\hline EAHX, D = 110 mm & 29.57 & 126.26 \\
\hline EAHX, D = 160 mm & 28.32 & 112.43 \\
\hline EAHX, D = 200 mm & 27.81 & 110.88 \\
\hline EAHX, D = 400 mm & 27.13 & 109.43 \\
\hline \hline Solution / City & \multicolumn{2}{|}{} \\
\cline { 2 - 3 } & heating \\
\hline without EAHX & 50.31 & cooling \\
\hline EAHX, D = 110 mm & 36.73 & 114.01 \\
\hline EAHX, D = 160 mm & 35.55 \\
\hline EAHX, D = 200 mm & 34.93 \\
\hline EAHX, D = 400 mm & 34.13 & 101.74 \\
\hline \hline
\end{tabular}

Energy savings achieved by introducing the earth-air heat exchanger within the mechanical ventilation system of the dwelling are also highlighted in Table VI.

Based on the values in Table $\mathrm{V}$, it is found that by using the earth-air heat exchanger within the mechanical ventilation system of the house, energy savings for heating are between $8 \ldots 16 \mathrm{kWh} / \mathrm{m}^{2}$,year. This means overall $960 \ldots 1920$ $\mathrm{kWh} /$ year heating savings for the house taken into account, with $120 \mathrm{~m}^{2}$ total floor area. On the other hand, the analysis of the results clearly reveals the climate influence. For this reason, the cutbacks are most important for the house located in Iasi, while the lowest energy heating reductions occur at Constanta (winter with obvious marine influence).

TABLE VI: ENERGY SAVINGS (KWH/M², YEAR)

\begin{tabular}{|c|c|c|}
\hline \multirow{2}{*}{ Solution / City } & \multicolumn{2}{|c|}{ Constanța } \\
\hline & heating & cooling \\
\hline EAHX, D = $110 \mathrm{~mm}$ & 8.24 & 13.65 \\
\hline EAHX, D = $160 \mathrm{~mm}$ & 9.15 & 15.16 \\
\hline EAHX, D = $200 \mathrm{~mm}$ & 9.51 & 15.81 \\
\hline EAHX, D $=400 \mathrm{~mm}$ & 10.01 & 16.61 \\
\hline \multirow{2}{*}{ Solution / City } & \multicolumn{2}{|c|}{ Bucharest } \\
\hline & heating & cooling \\
\hline EAHX, D = $110 \mathrm{~mm}$ & 11.41 & 13.84 \\
\hline EAHX, D = $160 \mathrm{~mm}$ & 12.66 & 15.38 \\
\hline EAHX, D = $200 \mathrm{~mm}$ & 13.17 & 16.01 \\
\hline EAHX, D = $400 \mathrm{~mm}$ & 13.85 & 16.83 \\
\hline \multirow{2}{*}{ Solution / City } & \multicolumn{2}{|c|}{ Iaşi } \\
\hline & heating & cooling \\
\hline EAHX, D = $110 \mathrm{~mm}$ & 13.58 & 12.27 \\
\hline EAHX, D = $160 \mathrm{~mm}$ & 14.76 & 13.35 \\
\hline EAHX, D = $200 \mathrm{~mm}$ & 15.38 & 13.90 \\
\hline EAHX, D = $400 \mathrm{~mm}$ & 16.17 & 14.64 \\
\hline
\end{tabular}

Concerning summer situation, cooling energy savings are between $12 \ldots 17 \mathrm{kWh} / \mathrm{m}^{2}$, year, which means for the house total floor area of $120 \mathrm{~m}^{2}$, total economy for cooling of $1440 \ldots 2040 \mathrm{kWh} /$ year. This time, as expected due to weather conditions, more substantial savings are attained in Constanta and Bucharest.

\begin{tabular}{|c|c|c|c|c|c|}
\hline $\begin{array}{c}\text { EAHX } \\
\text { diameter/ } \\
\text { solution }\end{array}$ & City & $\begin{array}{c}110 \\
(\mathrm{~mm})\end{array}$ & $\begin{array}{c}160 \\
(\mathrm{~mm})\end{array}$ & $\begin{array}{c}200 \\
(\mathrm{~mm})\end{array}$ & $\begin{array}{c}400 \\
(\mathrm{~mm})\end{array}$ \\
\hline \multirow{3}{*}{$\begin{array}{l}\text { electric } \\
\text { heating + } \\
\text { cooling }\end{array}$} & Constanța & 1534 & 1704 & 1773 & 1866 \\
\hline & Bucharest & 1922 & 2134 & 2221 & 2335 \\
\hline & Iaşi & 2086 & 2305 & 2400 & 2528 \\
\hline \multirow{3}{*}{$\begin{array}{l}\text { gas heating } \\
\text { + cooling }\end{array}$} & Constanța & 1586 & 1762 & 1833 & 1929 \\
\hline & Bucharest & 1994 & 2214 & 2305 & 2423 \\
\hline & Iaşi & 2170 & 2398 & 2497 & 2630 \\
\hline \multirow{3}{*}{$\begin{array}{l}\text { condensing } \\
\text { gas } \\
\text { technique } \\
\text { heating + } \\
\text { cooling }\end{array}$} & Constanța & 1445 & 1604 & 1669 & 1757 \\
\hline & Bucharest & 1798 & 1996 & 2078 & 2184 \\
\hline & Iaşi & 1941 & 2144 & 2232 & 2351 \\
\hline \multirow{3}{*}{$\begin{array}{l}\text { liquid fuel } \\
\text { heating + } \\
\text { cooling }\end{array}$} & Constanța & 1644 & 1826 & 1900 & 2000 \\
\hline & Bucharest & 2074 & 2303 & 2397 & 2520 \\
\hline & Iaşi & 2264 & 2502 & 2604 & 2744 \\
\hline \multirow{3}{*}{$\begin{array}{l}\text { wood } \\
\text { heating + } \\
\text { cooling }\end{array}$} & Constanța & 1958 & 2174 & 2263 & 2381 \\
\hline & Bucharest & 2509 & 2785 & 2899 & 3048 \\
\hline & Iaşi & 2770 & 3064 & 3190 & 3360 \\
\hline \multirow{3}{*}{$\begin{array}{l}\text { wood } \\
\text { gasification } \\
\text { heating + } \\
\text { cooling }\end{array}$} & Constanța & 1709 & 1897 & 1975 & 2078 \\
\hline & Bucharest & 2164 & 2402 & 2500 & 2629 \\
\hline & Iaşi & 2368 & 2617 & 2725 & 2871 \\
\hline \multirow{3}{*}{$\begin{array}{l}\text { pellet } \\
\text { heating }+ \\
\text { cooling }\end{array}$} & Constanța & 1644 & 1826 & 1900 & 2000 \\
\hline & Bucharest & 2074 & 2303 & 2397 & 2520 \\
\hline & Iaşi & 2264 & 2502 & 2604 & 2744 \\
\hline
\end{tabular}

We estimated also heating and cooling energy savings (Table VII) as well as corresponding greenhouse gas emissions reductions (Table VIII) in comparison with the classical solution: house without earth-air heat exchanger, equipped with gas fired boiler and direct expansion air conditioning plant (electrical mechanical compression cooling system). We considered for each type of energy source (Table VII) its acknowledged efficiency as follows: 
electric heating 1 , gas heating 0.95 , condensing gas technique heating 1.1 , liquid fuel heating 0.9 , wood heating 0.7 , wood gasification heating 0.85 , pellet heating 0.9 and electrical mechanical compression cooling 3 .

The results in Table VIII are presented in terms of resulting $\mathrm{CO}_{2}$ emissions per year, taken into account specific factors to convert " $\mathrm{kWh}$ " into " $\mathrm{CO}_{2}$ emissions" and " $\mathrm{kg}$ of carbon dioxide equivalent" for different heating energy sources and electrical mechanical compression cooling [22].

Depending on the heating and cooling solution efficiency, and the nature of the energy used (how "clean" is it), we salvage between 89 and $635 \mathrm{~kg}$ of $\mathrm{CO}_{2}$ emissions per year.

TABLE VIII: $\mathrm{CO}_{2}$ EMISSIONS SAVINGS (KG/YEAR)

\begin{tabular}{|c|c|c|c|c|c|}
\hline $\begin{array}{c}\text { EAHX } \\
\text { diameter/ } \\
\text { solution }\end{array}$ & City & $\begin{array}{c}110 \\
(\mathrm{~mm})\end{array}$ & $\begin{array}{c}160 \\
(\mathrm{~mm})\end{array}$ & $\begin{array}{l}200 \\
(\mathrm{~mm})\end{array}$ & $\begin{array}{l}400 \\
(\mathrm{~mm})\end{array}$ \\
\hline \multirow{3}{*}{$\begin{array}{l}\text { electric } \\
\text { heating + } \\
\text { cooling }\end{array}$} & Constanța & 271 & 300 & 313 & 329 \\
\hline & Bucharest & 356 & 396 & 412 & 433 \\
\hline & Iaşi & 402 & 445 & 463 & 488 \\
\hline \multirow{3}{*}{$\begin{array}{l}\text { gas heating } \\
+ \text { cooling }\end{array}$} & Constanța & 262 & 291 & 303 & 319 \\
\hline & Bucharest & 345 & 383 & 399 & 419 \\
\hline & Iaşi & 388 & 430 & 448 & 472 \\
\hline \multirow{3}{*}{$\begin{array}{l}\text { condensing } \\
\text { gas } \\
\text { technique } \\
\text { heating + } \\
\text { cooling }\end{array}$} & Constanța & 233 & 259 & 270 & 284 \\
\hline & Bucharest & 305 & 338 & 352 & 370 \\
\hline & Iaşi & 342 & 378 & 394 & 415 \\
\hline \multirow{3}{*}{$\begin{array}{l}\text { liquid fuel } \\
\text { heating + } \\
\text { cooling }\end{array}$} & Constanța & 346 & 384 & 400 & 420 \\
\hline & Bucharest & 460 & 511 & 532 & 559 \\
\hline & Iaşi & 523 & 579 & 603 & 635 \\
\hline \multirow{3}{*}{$\begin{array}{l}\text { wood } \\
\text { heating + } \\
\text { cooling }\end{array}$} & Constanța & 100 & 111 & 116 & 122 \\
\hline & Bucharest & 120 & 133 & 139 & 146 \\
\hline & Iaşi & 126 & 139 & 145 & 153 \\
\hline \multirow{3}{*}{$\begin{array}{l}\text { wood } \\
\text { gasification } \\
\text { heating }+ \\
\text { cooling }\end{array}$} & Constanța & 91 & 101 & 105 & 111 \\
\hline & Bucharest & 108 & 120 & 125 & 131 \\
\hline & Iaşi & 112 & 123 & 128 & 135 \\
\hline \multirow{3}{*}{$\begin{array}{l}\text { pellet } \\
\text { heating }+ \\
\text { cooling }\end{array}$} & Constanța & 89 & 98 & 102 & 108 \\
\hline & Bucharest & 105 & 116 & 121 & 127 \\
\hline & Iaşi & 108 & 119 & 124 & 130 \\
\hline
\end{tabular}

\section{CONCLUSION}

The developed model allows describing in unsteady conditions the functioning of earth-air heat exchanger and their coupling with building ventilation systems.

The results make available the contribution and efficiency of this solution to cover the buildings energy consumption for heating and cooling of fresh air. Moreover, case studies taken into consideration for three Romanian climates demonstrate that earth-air heat exchangers can be used as feasible (and inexpensive) complement to conventional heating or air conditioning systems for pretreatment (heating or cooling) of the air within ventilation systems. Energy gains can reach roughly $2000 \mathrm{kWh} /$ year for heating under severe winter conditions and can even overcome $2000 \mathrm{kWh} /$ year for cooling in continental climate (with or without some maritime influences).

In addition, greenhouse gas emissions can be equally reduced. $\mathrm{CO}_{2}$ emissions savings can attain more than half a ton/year in some circumstances (e.g. when liquid fuel fired boilers are employed for heating and direct expansion air conditioning -electrical mechanical compression for cooling).
Further, it is worthwhile to draw the attention to the fact that the use of earth-air heat exchangers implies no chemicals, compressors, burners or other complicated and polluting equipments. The earth-air heat exchanger system needs only fans (already required for the mechanical ventilation system).

Finally, it is worthwhile to mention, as one of the main perspective of this study and its results, the analysis of condensation phenomena inside the buried pipes of the earth-air heat exchanger system. Consequently, the dehumidifying process of humid air that takes naturally place through the earth-air heat exchanger system in the summer can play a significant role in reducing the latent cooling load of buildings. On the other hand, this subject is of particular concern in the case of requirements for acceptable indoor air quality for very high occupant density buildings.

\section{REFERENCES}

[1] I. Pop, M. T. Andrei, C. V. Ene, R. Alexe, F. Vartolomei, and P. S Nedea, "The strategy of European Union regarding climate change," International Journal of Energy and Environment, vol. 5, pp. 558-565, 2011.

[2] V. Pozeb, D. Goričanec, and T. Krope, "The future of Europe's energy policy: The legislative framework and the soft law instruments,' International Journal of Energy, vol. 5, pp. 88-95, 2011.

[3] I. Sârbu and C. Sebarchievici, "Thermal rehabilitation of buildings," International Journal of Energy, vol. 5, pp. 43-52, 2011.

[4] A. Audenaert and S. H. de Cleyn, "Cost benefit analysis of passive houses and low-energy houses compared to standard houses," International Journal of Energy, vol. 4, pp. 46-53, 2010.

[5] H. Voll, E. Seinre, and M. Sööt, "Analysis of heating energy of ventilation and underground heat exchanger in North European passive houses," International Journal of Energy and Environment, vol. 6, pp. 92-100, 2012.

[6] F. Ascione, L. Bellia, and F. Minichiello, "Earth-to-air heat exchangers for Italian climates,” Renewable Energy, vol. 36, pp. 2177-2188, 2011.

[7] J. Pfafferott, "Evaluation of earth-to-air heat exchangers with a standardized method to calculate energy efficiency," Energy and Buildings, vol. 35, pp. 971-983, 2003.

[8] P. Hollmuller, "Utilisation des échangeurs air-sol pour le chauffage et le rafraîchissement des bâtiments," Ph. D. dissertation, Université de Genève, Genève, Switzerland, 2002.

[9] M. de Paepe and A. Janssens, "Thermo-hydraulic design of earth-air heat exchangers," Energy and Buildings, vol. 35, pp. 389-397, 2003.

[10] M. K. Ghosal and G. N. Tiwari, "Modeling and parametric studies for thermal performance of an earth to air heat exchanger integrated with a greenhouse," Energy Conversion and Management, vol. 47, pp. 1779-1798, 2006.

[11] V. Bădescu, "Simple and accurate model for the ground heat exchanger of a passive house," Renewable Energy, vol. 32, pp. 845-855, 2007.

[12] S. Thiers, "Bilans énergétiques et environnementaux de bâtiments á énergie positive," Ph.D. dissertation, Ecole Nationale Supérieure des Mines de Paris, Paris, France, 2008.

[13] M. Maerefat and A. P. Haghighi, "Passive cooling of buildings by using integrated earth to air heat exchanger and solar chimney," Renewable Energy, vol. 35, pp. 2316-2324, 2010.

[14] V. Bansal, R. Misra, G. D. Agrawal, and J. Mathur, "Performance analysis of earth-pipe-air heat exchanger for winter heating," Energy and Buildings, vol. 41, pp. 1151-1154, 2009.

[15] V. Bansal, R. Misra, G. D. Agrawal, and J. Mathur, "Performance analysis of earth-pipe-air heat exchanger for summer cooling," Energy and Buildings, vol. 42, pp. 645-648, 2010.

[16] J. Vaz, M. A. Sattler, E. D. D. Santos, and L. A. Isoldi, "Experimental and numerical analysis of an earth-air heat exchanger," Energy and Buildings, vol. 43, pp. 2476-2482, 2011.

[17] S. A. Klein et al., TRNSYS Version 14.2. User Manual, Solar Energy Laboratory, University of Wisconsin, 1996.

[18] R. Wagner, S. Beisel, A. Spieler, and K. Vajen, "Measurement, modeling and simulation of an earth-to-air heat exchanger in Marburg (Germany)," in Proc. ISES Europe Solar Congress, Copenhagen, Denmark, 2000.

[19] P. Duchaufour, Introduction á la science du sol; Paris: Dunod, 2001. 
[20] Order No. 2513/22.11.2010, Romanian Ministry of Regional Development and Toursim (MDRT) Approving the Amendment of Technical Regulation C107/2005 (Thermo-technical Calculation of Buildings' Construction Elements).

[21] R. Hohotă, I. Colda, D. Enache, M. Găvan, and R. Enache, "Etude numérique des 'puits canadiens' pour la diminution des consommations énergétiques liées à la ventilation des bâtiments," in Proc. IBPSA France, Lyon, France, 2008.

[22] Building energy performance calculation methodology, Romanian Ministry of Regional Development and Tourism (MDRT), MC 001/2-2006.

Cătălin Teodosiu was born in Bucharest, Romania on July 22, 1972. He received the B.E. degree in civil engineering in 1996, the M.Sc. degree in energy management in 1997 from the Technical University of Civil Engineering, Bucharest, Romania and the Ph.D. degree in civil engineering in 2001 from the National Institute of Applied Science (INSA) of Lyon, France.

From 1996, he joined the Thermo-Hydraulic and Protection of the Atmosphere Systems Department, Faculty of Building Services and Equipment, Technical University of Civil Engineering, Bucharest. He also performed teaching and research activity in France as an assistant lecturer and a researcher from 1998 to 2004 in University Claude Bernard - Lyon I, INSA of Lyon and CETHIL - The Center for Thermal Sciences of Lyon. He is the author and co-author of 4 books and university courses. His current research interests include CFD (computational fluid dynamics) modeling, focusing on turbulence models and integrated heat-airflow-moisture models.

Assoc. Prof. C. Teodosiu was the vice-president of Romanian Association of Building Services Engineers-Bucharest Subsidiary, a member of Energy Auditors Order Romania and a member of Scientific and Advisory Committee RCEPB (Romanian Conference on Energy Performance of Buildings).
Lidia Niculiță was born in Bucharest, Romania on July 10, 1948. He received the B.E. degree in mechanical engineering in 1972 and the Ph.D. degree in mechanical engineering in 1997 from the Polytechnic University of Bucharest, Romania. She was a mechanical engineer at Machines, Tools and Units Enterprise, Bucharest and a researcher at National Institute of Research and Development for Precision Mechanics-INCDMF, Bucharest, Romania. Between 1999 and 2002, she was the director of Quality Assurance Department within Managerial Agency for Scientific Research, Innovation and Technological Transfer-Polytechnic University of Bucharest. She joined Faculty of Building Services Engineering-Technical University of Civil Engineering Bucharest in 2002. She is also the director of Quality Assurance Department within Technical University of Civil Engineering Bucharest. She is a specialty consultant for the National R\&D programs, developing of information packages for national programs, Quality Management. Her main research field covers the project management of scientific studies.

Raluca Teodosiu was born in Bucharest, Romania on April 11, 1976. He received the B.E. degree in civil engineering in 1999, the M.Sc. degree in civil engineering in 2000 from the Technical University of Civil Engineering, Bucharest, Romania and the Ph.D. degree in civil engineering in 2004 from the National Institute of Applied Science (INSA) of Lyon, France. She was an engineer at the Institute for Studies and Power Engineering (ISPE), Bucharest, Romania and she was also a research engineer at CETHIL - The Center for Thermal Sciences of Lyon. She was an assistant lecturer and a researcher at University Claude Bernard - Lyon I and CETHIL, France. She joined Faculty of Building Services Engineering-Technical University of Civil Engineering Bucharest in 2004 Her current research interests include CFD (computational fluid dynamics) modeling, experimental investigations concerning indoor air quality and energy consumption of buildings. 